\title{
Analisis Strategi Pemasaran Pada Lembaga Kursus dan Bimbingan Belajar Education Zone
}

\author{
Shinta Abdul Rahman \\ Fakultas Ekonomi dan Bisnis Islam, Program Studi Ekonomi Syariah, IAIN Fattahul Muluk Papua, Jayapura, Indonesia \\ Email: shintaabdulrahman@gmail.com \\ Submitted: 25 Januari 2021; Accepted: 12 Februari 2021; Published: 28 Februari 2021
}

\begin{abstract}
Abstrak-Keberhasilan Lembaga Kursus dan Bimbingan Belajar (LKBB) Education Zone (E-Zone) dalam menjual produk, ditentukan oleh kegiatan pemasaran sebagai ujung tombak yang telah ditetapkan oleh manajemen LKBB E-Zone beserta strategi pemasarannya. Dalam menentukan strategi pemasaran analisis lingkungan sangat penting karena mencakup analisis lingkungan internal dan eksternal. Adapun rumusan masalah dalam penelitian ini adalah : "Bagaimana Strategi Pemasaran Jasa pada Lembaga Kursus dan Bimbingan (LKBB) Education Zone (E-Zone) Kotaraja”. Sedangkan persoalan dalam penelitian ini adalah (1) Apa kekuatan dan kelemahan dalam meningkatkan pemasaran jasa LKBB E-Zone Kotaraja, (2) Apa peluang dan ancaman dalam meningkatkan pemasaran jasa LKBB E-Zone Kotaraja, (3) Apa rumusan strategi pemasaran dalam meningkatkan pemasaran jasa LKBB E-Zone Kotaraja. Tujuan dari penelitian ini : (1) Mengidentifikasi kekuatan dan kelemahan pada LKBB E-Zone, (2) Mengidentifikasi peluang dan ancaman pada LKBB E-Zone, (3) Merumuskan strategi pemasaran LKBB E-Zone. Satuan Analisis dalam peneitin ini adalah Lembaga Kursus dan Bimbingan Belajar Education Zone (LKBB E-Zone) dan satuan pengamatannya adalah manajemen yang mengelola strategi pemasaran dan penjualan serta siswa-siswi yang sudah belajar di LKBB E-Zone selama kurang lebih 6 (enam) bulan. Metode analisa data yang digunakan dalam penelitian ini adalah Analisis SWOT (Strength, Weakness, Opportunity, Threat), yaitu suatu analisis yang bertujuan untuk menganalisis kekuatan dan kelemahan serta peluang dan ancaman. Hasil penelitian dan analisis menunjukkan LKBB E-Zone berada dalam posisi kuadran Strategi Pertumbuhan Cepat. Dimana dalam Diagram SWOT strategi pemasaran berada diantara kekuatan (Strength) dan peluang (Opportunity). LKBB E-Zone memiliki kekuatan dan peluang yang lebih besar dari kelemahan dan ancaman. Sehingga LKBB E-Zone dapat memanfaatkan secara maksimal seluruh potensi kekuatan dan peluang dengan menggunakan unsur-unsur strategi pemasaran yaitu: Segmentasi pasar, Penentuan pasar sasaran, Penempatan produk, Penentuan waktu, Bauran pemasaran dan unsur-unsur pentingnya pada 7 (tujuh) P yaitu : Promotion, Product, Price, Place, People, Physical avidence, dan Process.
\end{abstract}

Kata Kunci: Strategi Pemasaran, E-Zone, LKKB, Analisa SWOT

Abstract-Marketing activities determine the Education Zone Course and Tutoring Institute (E-Zone LKBB) in selling products as the spearhead set by the E-Zone management LKBB and its marketing strategy. In determining the marketing strategy, environmental analysis is critical because it includes analyzing the internal and external environment. The research problem is about the service marketing strategy in the E-Zone LKBB. Therefore the research questions in this research are: 1) What are the strengths and weaknesses in improving LKBB E-Zona services. 2) What are the opportunities and threats in increasing the marketing strategy of LKBB E-Zone services? 3) What are the formulations of marketing strategies in improving marketing LKBB E-Zone services? This study aims to identify the strengths and weaknesses in the LKBB E-Zone as well as the opportunities and threats of the E-Zone LKBB and formulate a marketing strategy for LKBB E-Zone. The unit of analysis in this research is the Education Zone Course and Tutoring Institution. The observation unit is the marketing and sales management and the students who have studied at LKBB EZone for approximately six months. The data analysis method used in this study is the SWOT analysis (Strength, Weakness, Opportunity, Threat), which is an analysis that aims to analyze the strengths and weaknesses as well as opportunities and threats. The result shows that the E-Zone LKBB is in the Fast Growth Strategy quadrant position, between Strength (Strength) and opportunity (Opportunity) in the SWOT diagram. LKBB E-Zone has strengths and opportunities that are greater than weaknesses and threats. So that LKBB E-Zone can take full advantage of all the potential strengths and opportunities by using elements of marketing strategies, namely: market segmentation, target market determination, product placement, timing, marketing mix, and its essential $7 \mathrm{P}$ ele ments, namely: Promotion, Product, Price, Place, People, Physical Evidence, and Process.

Keywords: Marketing Strategy, E-Zone, LKKB, SWOT Analysis

\section{PENDAhULUAN}

Setiap perusahaan, baik yang bergerak di bidang barang ataupun jasa, mempunyai tujuan untuk tetap hidup dan berkembang. Tujuan tersebut dapat dicapai agar dapat mempertahankan dan meningkatkan tingkat keuntungan atau laba operasional perusahaan. Hal ini dapat dilakukan, jika perusahaan mampu mempertahankan dan meningkatkan penjualan barang atau jasa yang mereka produksi. Melakukan penerapan strategi pemasaran yang akurat dengan pemanfaatan peluang dalam meningkatkan penjualan, sehingga posisi atau kedudukan perusahaan di pasar dapat ditingkatkan atau dipertahankan. Sehubungan dengan hal tersebut, pelaksanaan pemasaran modern saat ini mempunyai peranan yang sangat besar sebagai penunjang langsung terhadap peningkatan laba perusahaan.

Strategi pemasaran adalah suatu rencana yang terurai di bidang pemasaran. Agar memperoleh hasil yang optimal, strategi pemasaran mempunyai ruang lingkup yang luas di bidang pemasaran diantaranya adalah strategi dalam menghadapi persaingan, strategi harga, strategi produk, strategi pelayanan dan sebagainya. Pemasaran di suatu perusahaan bersifat dinamis, sehingga perusahaan harus selalu menerapkan prinsip-prinsip yang unggul dan terusmenerus melakukan inovasi. Dalam menyusun strategi pemasaran perusahaan perlu mengenali kekuatan dan kelemahannya dalam persaingan. Hal ini akan sangat membantu dalam mengenali diri, serta memanfaatkan setiap peluang yang ada. Karena dunia pemasaran saat ini bukanlah jaman dimana produsen memaksakan kehendak terhadap konsumen, melainkan sebaliknya konsumen memaksakan kehendaknya terhadap produsen. 
Dapat ditarik sebuah kesimpulan bahwa pemasaran merupakan suatu proses sosial dan managerial di mana individu dan kelompok mendapatkan kebutuhan dan keinginan mereka dengan menciptakan, menawarkan dan bertukar sesuatu yang bernilai satu sama lain. Pemasaran tidak hanya berfungsi menyampaikan produk atau jasa hingga sampai ke tangan konsumen, tetapi bagaimana produk atau jasa tersebut dapat memberikan kepuasan kepada pelanggan dengan menghasilkan laba. (Khasanah, 2015). Sebagai penghubung antara produsen dan konsumen, maka harus dirancang suatu strategi pemasaran sedemikian rupa yang mampu memenuhi kedua kebutuhan tersebut. Pemilihan strategi pemasaran yang tepat, mampu meningkatkan penjualan suatu produk tanpa menambah beban biaya secara signifikan. Pemilihan strategi pemasaran yang tepat inilah sesungguhnya yang menjadi inti kegiatan pemasaran saat ini dan menjadi bidang kajian yang dilakukan terus-menerus untuk menyesuaikan dengan kondisi lingkungan yang terus berubah. Hal serupa juga diuangkapkan oleh (Afrilita, 2013) bahwa keberhasilan atau kegagalan perusahaan tergantung dari manajemen perusahaan tersebut, manajemen perusahaan harus bisa memahami lingkungan eksternal perusahaan secara lengkap dan akurat dalam pengembangan strategi pemasaran. Beberapa penelitian terdahulu seperti yang dilakukan oleh Suranta (2015) dan Wibowo et al., (2015) menemukan bahwa strategi pemasaran yang diterapkan secara tepat dapat meningkatkan laba dan daya saing perusahaan. Penelitian lain yang dilakukan oleh Setyorini \& Santoso (2016) juga memberikan alternatif strategi pemasaran yang cocok untuk bisnis yang dijalankan berdasarkan analisis yang telah dilakukannya.

Lembaga Kursus dan Bimbingan Belajar (LKBB) Education Zone (E-Zone) adalah suatu lembaga kursus dan bimbingan belajar yang menjual jasa pendidikan yang berlokasi di Kotaraja Jayapura. E-Zone adalah satu-satunya lembaga kursus dan bimbingan belajar yang berbasir Accelerated Psychology Learning and Practice Class. Sebuah metode yang menggabungkan kemudahan dan pendekatan anak dalam belajar. Metode tersebut telah terbukti dalam mempercepat proses belajar siswa didik. Saat ini E-Zone dalam upaya untuk mengenalkan lembaga tersebut ke masyarakat Kota Jayapura. Melihat bisnis dalam pendidikan jasa yang masih berpotensi maka E-Zone berupaya untuk memenuhi kebutuhan masyarakat dalam bidang pendidikan. Dengan melakukan penelitian ini maka kontribusi yang diharapkan adalah mampu memberikan gambaran umum maupun gambaran secara khusus tentang bagaimana strategi yang paling cocok digunakan oleh perusahaaan di bidang jasa khususnya LKBB E-Zone.

Dengan latar belakang di atas, menjadi dasar pertimbangan penulis untuk mengetahui bagaimana penerapan strategi pemasaran yang dilakukan E-Zone dalam meningkatkan volume penjualannnya.

\section{KERANGKA TEORI}

Pemasaran adalah suatu proses sosial yang dengan proses itu individu dan kelompok mendapatkan apa yang mereka butuhkan dan inginkan dengan menciptakan, menawarkan dan secara bebas mempertukarkan produk dan jasa yang bernilai dengan pihak lain. Sedangkan menurut Herman Kartajaya, pemasaran adalah sebuah disiplin bisnis strategi yang mengarahkan proses penciptaan, penawaran, dan perubahan values dari satu inisiator kepada stakeholders-nya (Kotler, 2005) Terdapat beberapa strategi pemasaran yaitu :

\subsection{Segmentasi Pasar}

Pasar terdiri dari pembeli yang berbeda-beda dalam berbagai hal dan keinginan. Karena masing-masing memiliki kebutuhan dan keinginan yang unik, setiap pembeli merupakan pasar potensial tersendiri. Oleh sebab itu penjual idealnya merancang program pemasarannya tersendiri bagi masing-masing pembeli. Segmentasi yang lengkap membutuhkan biaya yang tingi dan kebanyakan pelanggan tidak dapat membei produk yang benar-benar disesuaikan dengan kebutuhan. sehingga, perusahaan mencari kelas-kelas pembeli yang lebih besar dengan kebutuhan produk atau tanggapan pembeli yang berbeda-beda. Segmen pasar terdiri dari sekelompok pelanggan yang memiliki seperangkat keinginan yang sama (Kotler, 2005).

\subsection{Penentuan Pasar Sasaran}

Setelah perusahan mimilih segmen pasar, strategi berikutnya adalah menentukan target pasar atau pasar sasaran. Penentuan pasar sasaran merupakan proses mengevaluasi dan memilih satu atau beberapa segmen pasar yang dinilai paling menarik untuk dilayani dengan program pemasaran spesifik (Tjiptono \& Chandra, 2011).

\subsection{Penentuan Posisi}

Secara umum penentuan posisi adalah tindakan untuk merangsang produk dan bauran pemasaran supaya dapat tercipta kesan tertentu yang mudah diingat oleh konsumen, sehingga dengan demikian konsumen segmen yang terpilih mampu memahami dan menghargai apa yang dilakukan oleh perusahaan. Bila sebuah merek mampu menemukan penempatan produk yang efektif, tim merek sering dan sangat bijak memempertahankannya dan menggunakannya lagi dan lagi.

Penentuan posisi adalah bagaimana kita dapat menempatkan produk dan merek di benak pelanggan. Dari definisi tersebut tercermin bahwa perang pemasaran bukanlah terletak di pasar, tapi di benak pelanggan. Perang pemasaran adalah perang untuk memperebutkan ruang di benak pelanggan (Hermawan, 2008).

\subsection{Penentuan Waktu}

Menentukan waktu yang tepat atau yang paling sesuai, secara tidak langsung sama dengan memetakan sasaran kita. Perusahaan dituntut untuk dapat membuat kategori waktu yang disesuaikan dengan jenis produk yang kita miliki, 
kemudian barulah sasaran dipilah-pilah berdasarkan kategori waktu yang telah dibuat. Atau dapat dikatakan menyesuaikan dengan momentnya.

Penentuan waktu yang tepat dapat mempermudah pemasaran. Karena tingkat kebutuhan masyarakat bersifat dinamis, selalu berubah-ubah sesuai dengan waktu berdasarkan kebutuhan masyarakat, perusahaan akan sangat terbantu dalam melakukan pemasaran jika dapat mengikuti irama waktu kebutuhan konsumen . Pemasaran bisa lebih efektif dan maksimal bila sesuai dengan momentya. Pemilihan waktu yang tepat untuk memasuki pasar merupakan salah satu alasan utama penyebab keberhasilan atau kegagalan produk baru.Penentuan saat yang tepat dalam memsarkan produk merupakan hal yang sangat perlu diperhatikan. Meskipun perusahaan melihat adanya kesempatan baik namun perusahan harus terlebih dahulu melakukan persiapan.

\subsection{Bauran Promosi}

Bauran pemasaran jasa merupakan seperangkat alat yang dapat digunakan pemasar untuk membentuk karakteristik jasa yang ditawarkan kepada pelanggan. Alat-alat tersebut dapat dipergunakan untuk menyusun strategi jangka panjang dan merancang program taktik jangka pendek. Konsep bauran pemasaran pertama kali dipopulerkan oleh Mc. Carhty yang merumuskannya menjadi 4P yaitu Product, Price, Place, Promotion. Dalam perkembangannya, karena dianggap terlalu sempit untuk pemasaran jasa maka bauran pemasaran ditambah dengan empat unsur lainnya, yaitu People, Process dan Physical Evidence, Customer Service (Tjiptono \& Chandra, 2011).

\subsection{Analisa SWOT}

Analisis SWOT adalah evaluasi dari kekuatan dan kelemahan internal suatu perusahaan yang dilakukan secara teliti dan juga evaluasi terhadap peluang dan ancaman dari lingkungan. Dalam analisis SWOT, strategi terbaik untuk mencapai misi suatu perusahaan adalah dengan : (1) mengeksploitasi peluang dan kekuatan suatu perusahaan, dan pada saat yang sama, (2) menetralisasikan ancamannya, dan (3) menghindari atau memperbaiki kelemahannya (Rangkuti, 2004).

\section{METODOLOGI PENELITIAN}

\subsection{Jenis penelitian}

Metode penelitian pada dasarnya merupakan cara ilmiah untuk mendapatkan data dengan tujuan dan kegunaan tertentu. Berdasarkan hal tersebut terdapat empat kata kunci yang perlu diperhatikan yaitu, cara ilmiah, data, tujuan dan kegunaan (Sugiyono, 2013).

Penelitian yang digunakan oleh penulis adalah penelitian kualitatif. Menurut pendapat para ahli "penelitian kualitatif adalah data yang berbentuk kalimat, kata atau gabar”. (Sugiyono, 2007) Sedangkan menurut (Arikunto, 2006) "sumber data penelitian kualitatif adalah tampilan yang berupa kata-kata lisan atau tertulis yang dicermati oleh peneliti, dan benda-benda yang diamati sampai detailnya". Penelitian ini berusaha menghasilkan data deskriptif berupa kata-kata tertulis maupun lisan dari orang-orang yang perilakunya diamati.

\subsection{Satuan Analisis dan Satuan Pengamatan}

Satuan analisis adalah Lembaga Khursus dan Bimbingan Belajar E-Zone. Satuan pengamatan dalam penelitian ini adalah manajemen Lembaga Kursus dan Bimbingan Belajar E-Zone yang mengelola strategi pemasaran dan penjualan serta siswa-siswi yang sudah belajar di LKBB E-Zone selama kurang lebih 6 (enam) bulan.

\subsection{Teknis Analisis}

Sesuai dengan judul penelitian dan dari data yang diperoleh dari perusahaan selanjutnya dianalisis dengan menggunakan analisis pemecahan masalah yang berhubungan dengan strategi pemasaran. Dalam menentukan teknik analisis data yang digunakan tidak terlepas dari permasalahan yang ada. Pemecahan masalah dapat digunakan dengan cara desktiprif kualitatif.

Dalam penelitian ini cara pemberian skor yang digunakan adalah skala likert. Skala likert adalah skala yang digunakan untuk mengukur presepsi berdasarkan sikap atau pendapat seseorang atau kelompok mengenai sebuah peristiwa atau fenomena.

Dalam penelitian ini metode yang digunakan adalah Analisis SWOT (Strength, Weaknesses, Opportunity, Threat) yaitu suatu analisis yang bertujuan untuk menganalisis kekuatan dan kelemahan serta peluang dan ancaman. Analisis SWOT adalah analisis kondisi internal maupun eksternal perusahaan yang selanjutnya akan digunakan sebagai dasar untuk merancang dan program kerja. Analisis internal meliputi penilaian terhadap faktor kekuatan (Strength) dan kelemahan (Weaknesses). Sedangkan analisis eksternal mencakup faktor peluang (Opportunity) dan ancaman (Threat).

\section{HASIL DAN PEMBAHASAN}

Berdasarkan hasil penelitian dan pembahasan dapat disimpulkan Kekuatan pada Lembaga Kursus dan Bimbingan Belajar (LKBB) Education Zone E-Zone adalah kesesuaian produk, harga lebih murah, tempat yang startegis, memiliki pengajar yang bersahabat, jam belajar yang fleksibel, ruang belajar yang nyaman dan metode yang bervariatif. Kekuatan ini memiliki prosentase tinggi yaitu $0.85(85 \%)$. 
Tabel 1. Hasil Jawaban Responden Terhadap Kekuatan LKBB E-Zone

\begin{tabular}{|c|c|c|c|c|c|}
\hline \multirow{2}{*}{ No } & \multirow{2}{*}{ Indikator } & \multicolumn{2}{|c|}{ Skor } & \multirow{2}{*}{$\begin{array}{c}\text { Nilai } \\
\text { Rating }\end{array}$} & \multirow{2}{*}{ Persentase } \\
\hline & & Max. & Total & & \\
\hline 1 & $\begin{array}{l}\text { Program yang ditawarkan sesuai dengan } \\
\text { kebutuhan siswa dan kurikulum sekolah }\end{array}$ & 100 & 87 & 0,87 & $87 \%$ \\
\hline 2 & $\begin{array}{l}\text { Harga yang ditawarkan lebih murah dari } \\
\text { pesaing }\end{array}$ & 100 & 76 & 0,76 & $76 \%$ \\
\hline 3 & Tempat pendidikan yang strategis & 100 & 87 & 0,87 & $87 \%$ \\
\hline 4 & Tenaga pengajar yang bersahabat & 100 & 94 & 0,94 & $94 \%$ \\
\hline 5 & $\begin{array}{l}\text { Tenaga pengajar selalu memenuhi target yang } \\
\text { terstandar }\end{array}$ & 100 & 83 & 0,83 & $83 \%$ \\
\hline 6 & Jam belajar disesuaikan keinginan siswa & 100 & 81 & 0,81 & $81 \%$ \\
\hline 7 & Ruang belajar yang nyaman & 100 & 87 & 0,87 & $87 \%$ \\
\hline 8 & Metode belajar yang bervariatif & 100 & 88 & 0,88 & $88 \%$ \\
\hline & TOTAL SKOR & 800 & 683 & $\mathbf{0 , 8 5}$ & $85 \%$ \\
\hline
\end{tabular}

Kelemahan pada Lembaga Kursus dan Bimbingan Belajar (LKBB) Education Zone E-Zone usaha belum populer, promosi yang kurang, fasilitas pendukung yang belum lengkap, tenaga pengajar masih kuliah dan tenaga pengajar belum tetap. Kelemahan ini memiliki prosentase yang cukup rendah dan hal tersebut baik dalam kategori kelemahan yaitu $0.62(62 \%)$.

Tabel 2. Hasil Jawaban Responden Terhadap Kelemahan LKBB E-Zone

\begin{tabular}{|c|c|c|c|c|c|}
\hline \multirow{2}{*}{ No. } & \multirow{2}{*}{ Indikator } & \multicolumn{2}{|c|}{ Skor } & \multirow{2}{*}{$\begin{array}{l}\text { Nilai } \\
\text { Rating }\end{array}$} & \multirow{2}{*}{ Persentase } \\
\hline & & Max & Total & & \\
\hline 1 & Usaha belum cukup popular & 100 & 67 & 0,67 & $67 \%$ \\
\hline 2 & Kurangnya kegiatan promosi & 100 & 64 & 0,64 & $64 \%$ \\
\hline 3 & $\begin{array}{l}\text { Masih sulit memilih media yang tepat untuk } \\
\text { mempromosikan produk }\end{array}$ & 100 & 66 & 0,66 & $66 \%$ \\
\hline 4 & $\begin{array}{l}\text { Fasilitas pendukung yang masih belum } \\
\text { lengkap }\end{array}$ & 100 & 61 & 0,61 & $61 \%$ \\
\hline 5 & Belum tersedia tenaga pengajar yang tetap & 100 & 69 & 0,69 & $69 \%$ \\
\hline 6 & $\begin{array}{l}\text { Tenaga pengajar sebagian besar masih } \\
\text { kuliah }\end{array}$ & 100 & 67 & 0,67 & $67 \%$ \\
\hline 7 & Tenaga pengajar yang belum profesional & 100 & 43 & 0,43 & $43 \%$ \\
\hline 8 & $\begin{array}{l}\text { Harga yang ditawarkan sulit dijangkau untuk } \\
\text { kalangan menengah ke bawah }\end{array}$ & 100 & 56 & 0,56 & $56 \%$ \\
\hline & TOTAL SKOR & 800 & 493 & 0,62 & $62 \%$ \\
\hline
\end{tabular}

Adapun peluang dan ancaman pada LKBB E-Zone yaitu penduduk yang semakin meningkat, kebutuhan pendidikan yang tinggi, segmen pasar yang luas, lokasi pendidikan yang strategis, niat belajar siswa di tahun ajaran baru menigkat, pelayanan guru di sekolah kurang maksimal dan masih diterapkannya UN. Nilai peluang berada pada kategori tinggi yaitu $0.84(84 \%)$.

Tabel 3. Hasil Jawaban Responden Terhadap Peluang LKBB E-Zone

\begin{tabular}{|c|c|c|c|c|c|}
\hline \multirow{2}{*}{ No } & \multirow{2}{*}{ Indikator } & \multicolumn{2}{|c|}{ Skor } & \multirow{2}{*}{$\begin{array}{c}\text { Nilai } \\
\text { Rating }\end{array}$} & \multirow{2}{*}{ Persentase } \\
\hline & & Max. & Total & & \\
\hline 1 & Penduduk kota Jayapura makin meningkat & 100 & 77 & 0,77 & $77 \%$ \\
\hline 2 & $\begin{array}{l}\text { Kesadaran kebutuhan permintaan jasa } \\
\text { pendidikan terus meningkat }\end{array}$ & 100 & 85 & 0,85 & $85 \%$ \\
\hline 3 & $\begin{array}{l}\text { Permintaan masyarakat mulai terbuka untuk } \\
\text { pendidikan }\end{array}$ & 100 & 83 & 0,83 & $83 \%$ \\
\hline 4 & $\begin{array}{l}\text { Segmen pasar yang luas (Playgroup sampai } \\
\text { Umum) }\end{array}$ & 100 & 85 & 0,85 & $85 \%$ \\
\hline 5 & Lokasi pendidikan dekat dengan perumahan & 100 & 89 & 0,89 & $89 \%$ \\
\hline 6 & $\begin{array}{l}\text { Minat belajar siswa pada tahun ajaran baru } \\
\text { meningkat }\end{array}$ & 100 & 85 & 0,85 & $85 \%$ \\
\hline 7 & Pelayanan guru di sekolah kurang maksimal & 100 & 74 & 0,74 & $74 \%$ \\
\hline 8 & $\begin{array}{l}\text { Adanya Ujian Akhir Nasional yang } \\
\text { mendorong perlunya Bimbingan Belajar }\end{array}$ & 100 & 90 & 0,90 & $90 \%$ \\
\hline & TOTAL SKOR & 800 & 668 & $\mathbf{0 , 8 4}$ & $84 \%$ \\
\hline
\end{tabular}


Ancaman pada LKBB E-Zone yaitu anyak pesaing, teknologi pendidikan yang terus berkembang, minat belajar dimasa liburan menurun dan banyak sekolah yang melakukan bimbingan belajar. Prosentasi nilai pada kategori ini tergolong cukup rendah yaitu $0.69(69 \%)$ atau lebih kecil dari peluang yang dimiliki.

Tabel 4. Hasil Jawaban Responden Terhadap Ancaman LKBB E-Zone

\begin{tabular}{clcccc}
\hline \multirow{2}{*}{ No. } & \multicolumn{1}{c}{ Indikator } & \multicolumn{2}{c}{ Skor } & Nilai & \multirow{2}{*}{ Persentase } \\
\hline 1 & Banyak pesaing di sekitar wilayah operasional & 100 & 74 & 0,74 & $74 \%$ \\
2 & $\begin{array}{l}\text { Munculnya pesaing-pesaing baru } \\
\text { Rating }\end{array}$ & 100 & 77 & 0,77 & $77 \%$ \\
& $\begin{array}{l}\text { Teknologi pendidikan yang semakin } \\
\text { berkembang }\end{array}$ & 100 & 75 & 0,75 & $75 \%$ \\
& $\begin{array}{l}\text { Minat belajar siswa pada masa liburan } \\
4\end{array}$ & 100 & 81 & 0,81 & $81 \%$ \\
& $\begin{array}{l}\text { menurun } \\
5\end{array}$ & Banyak sekolah yang melakukan bimbingan \\
belajar & 100 & 73 & 0,73 & $73 \%$ \\
6 & $\begin{array}{l}\text { Kurikulum yang terus berubah-ubah } \\
\text { Program yang ditawarkan pesaing lebih }\end{array}$ & 100 & 75 & 0,75 & $75 \%$ \\
7 & $\begin{array}{l}\text { menarik } \\
\text { Jumlah produk yang ditawarkan tidak sesuai }\end{array}$ & 100 & 53 & 0,53 & $53 \%$ \\
$\quad \begin{array}{l}\text { dengan permintaan pelanggan } \\
\text { TOTAL SKOR }\end{array}$ & $\mathbf{8 0 0}$ & $\mathbf{5 5 4}$ & $\mathbf{0 , 6 9}$ & $\mathbf{6 9 \%}$ \\
\hline
\end{tabular}

Strategi pemasaran yang dimiliki LKBB E-Zone adalah starategi pertumbuhan cepat yang berada pada wilayah Diagram SWOT dimana titik temu peluang dan kekuatan yang dimiliki oleh LKBB E-Zone lebih besar dari kelemahan dan ancamannya.

Tabel 5. STRATEGY

\begin{tabular}{lccc}
\hline \multicolumn{1}{c}{ Indikator SWOT } & Rating & Selisih & Ket \\
\hline Kekuatan & 0,85 & 0,24 & $(+)$ \\
Kelemahan & 0,62 & & \\
$\begin{array}{l}\text { Peluang } \\
\text { Anacaman }\end{array}$ & 0,84 & 0,14 & $(+)$ \\
\hline
\end{tabular}

Strategi ini lebih memanfaatkan peluang dan kekuatan dalam mempercepat pertumbuhan LKBB E-Zone. Strategi segmentasi pasarnya adalah segmentasi pasar geografis (letak tempat pendidikan yang strategis) di distrik Abepura, Jayapura dan segmentasi pasar demografis (potensi pasar yang luas); strategi penentuan pasar sasarannya adalah pelanggan yang memiliki akses yang dapat dijangkau dan semua calon konsumen yang berada dalam segmen domografis (PAUD, TK, SD, SMP, dan SMA) di distrik Abepura, Jayapura; strategi penempatan produk dilakukan dengan membangun image produk di masyarakat dengan cepat, luas dikenal dan mudah diingat; strategi penentuan waktu dengan melakukan promosi yang maksimal pada awal tahun ajaran baru; strategi bauran pemasaran LKBB EZone melingkupi 7 (tujuh) unsur-unsur penting yang mendukung yaitu: (a) Promosi yang dilakukan oleh dengan cara periklanan, member get member, personal selling, dan sponsor event; (b) Produk LKBB E-zone adalah jasa pendidikan yang dikemas semenarik mungkin dengan pembelajaran interaktif dengan melibatkan audio visual maupun alat bantu lainnya; (c) Strategi pemberian harga yang digunakan dengan menetapkan harga yang lebih murah dari pesaing (sealed bit pricing) dan pemberian pemotongan harga (discount); (4) Tempat atau pendistribusiannya dengan penyaluran langsung tanpa perantara (direct distribution); (5) Memaksimalkan Sumber Daya Manusia yang dimiliki oleh LKBB EZone dalam menyajikan jasa pendidikan kepada pelanggan; (6) Bukti fisik bahwa LKBB E-Zone menjual jasa pendidikan yang semakin baik dengan bangunan fisik yang memadai; (7) Proses dari menghasilkan produk yang baik terkihat dari intensifnya pengemasan jasa yang ditawarkan dan menghasilakan produk yang berkualitas tinggi.

\section{KESIMPULAN}

Penelitian dan analisis terhadap LKBB E-Zone menunjukkan berada dalam posisi kuadran Strategi Pertumbuhan Cepat. Dimana dalam Diagram SWOT strategi pemasaran berada diantara kekuatan (Strength) dan peluang (Opportunity). LKBB E-Zone memiliki kekuatan dan peluang yang lebih besar dari kelemahan dan ancaman, sehingga LKBB E-Zone dapat memanfaatkan secara maksimal seluruh potensi kekuatan dan peluang dengan menggunakan unsur-unsur strategi pemasaran.

\section{DAFTAR PUSTAKA}

Afrilita, N. (2013). Analisis SWOT dalam menentukan strategi pemasaran sepeda motor pada PT. Samekarindo Indah di Samarinda. Journal Adminsitrasi Bisnis.

Arikunto, S. (2006). Prosedur Penelitian Suatu Tindakan Praktik. Jakarta: Rineka Cipta.

Hermawan, K. (2008). Seri 9 Hermawan Kertajaya on Marketing Mix. marketing mix. 
Khasanah, A. (2015). PEMASARAN JASA PENDIDIKAN SEBAGAI STRATEGI PENINGKATAN MUTU DI SD ALAM BATURRADEN. el-Tarbawi. https://doi.org/10.20885/tarbawi.vol8.iss2.art4

Kotler. (2005). Manajemen Pemasaran. In: Manajemen Pemasaran. In Edisi Millenium, Jilid 1.

Rangkuti, F. (2004). Teknik Membedah kasus Bisnis. Analisis SWOT.

Setyorini, H., \& Santoso, I. (2016). Analisis Strategi Pemasaran Menggunakan Matriks SWOT dan QSPM ( Studi Kasus : Restoran WS Soekarno Hatta Malang ). Jurnal Teknologi dan Manajemen Agroindustri.

Sugiyono. (2013). Metode Penelitian Pendidikan Pendekatan Kuantitaif, Kualitatif, dan R\&DSugiyono. 2013. "Metode Penelitian Pendidikan Pendekatan Kuantitaif, Kualitatif, dan R\&D.” Metode Penelitian Pendidikan Pendekatan Kuantitaif, Kualitatif, dan R\&D. https://doi.org/10.1. In Metode Penelitian Pendidikan Pendekatan Kuantitaif, Kualitatif, dan R\&D.

Suranta, G. F. (2015). Analisis Strategi Pemasaran Jasa Menghadapi Pesaing. Analisis Strategi Pemasaran Jasa Menghadapi Pesaing.

Tjiptono, F., \& Chandra, G. (2011). Service, Quality \& Satisfaction. In Edisi 4.

Wibowo, D. H., Arifin, Z., \& Sunarti, . (2015). Analisis Strategi Pemasaran Untuk Meningkatkan Daya Saing UMKM (Studi pada Batik Diajeng Solo). Jurnal Administrasi Bisnis. 